\title{
Evaluation of quality parameters and chromatographic, spectroscopic, and thermogravimetric profile of Patauá oil (Oenocarpus bataua)
}

\author{
Orquídea Vasconcelos dos SANTOS ${ }^{1,2 *}$ (D), Bruno Santos GONÇALVES ${ }^{3}$, Christine da Silva MACÊDO ${ }^{3}$, \\ Leyvison Rafael Vieira da CONCEIÇÃO ${ }^{4}$, Carlos Emmerson Ferreira COSTA ${ }^{4}$, \\ Ozéias Vieira MONTEIRO JÚNIOR ${ }^{4}$, Amanda Larissa Garça de SOUZA ${ }^{1}$, Suzana Caetano da Silva LANNES ${ }^{5}$
}

\begin{abstract}
The objective of this research was to evaluate the quality parameters and the chromatographic, thermogravimetric, and spectroscopic profile of Patauá oil (Oenocarpus bataua). All analyses were performed according to the Recommended Practices of the American Oil Chemists' Society (AOCS). The parameters obtained indicate conservation quality standards in accordance with Brazilian legislation. The fatty acid profile shows a predominance of $\omega-9, \omega-6$, and $\omega-3$ fatty acids. The thermogravimetric behavior and differential analysis indicated good stability upon gradual temperature increase and the presence of endothermic and exothermic peaks characteristic of thermal and oxidative decomposition at high temperatures only. The spectroscopic profile evidenced long-chain unsaturated fatty acids confirming the fatty acid profile results. It was found that, in general, the Patauá oil has good nutritional and functional quality and high thermal and oxidative stability; therefore it can be considered as a raw material with potential applications in various industries.
\end{abstract}

Keywords: oil; Patauá; thermogravimetry; infrared.

Practical Application: The study shows the potential of oil for use in the food, dermocosmetic and pharmaceutical sectors.

\section{Introduction}

The composition of fatty materials varies according to the extraction technique applied. Thus, their physicochemical, nutritional, functional, thermal, oxidative, and spectroscopic properties may undergo considerable changes during extraction and storage. Their fatty acid profile and antioxidant composition are directly related to their oxidative stability (Cuvelier \& Maillard, 2012; Irshad et al., 2015; Pereira et al., 2019; Carrillo et al., 2018).

The characteristics of the extracted materials can be monitored and evaluated using adequate extraction techniques that take into account aspects such as performance, quality, and thermal and oxidative stability of the material. Some commonly used techniques are solid-liquid extraction using of solvents, steam distillation, supercritical fluid extraction, and mechanical or hydraulic pressing. The last two have some advantages such as low cost, easy application and high extraction yield (Pighinelli et al., 2009; Santos et al., 2013a, b; Araújo et al., 2018).

Several studies have focused on identifying the best methods of oil extraction. Hydraulic pressing is one of the most commonly used methods for extraction of macro and micronutrients with important nutritional, functional, and technological properties. Within this context, oilseeds stand out since their high lipid content produces high oil yield and enables continuous flow

of functional and bioactive compounds (Chollet et al., 2012; Santos et al., 2013a; Pereira et al., 2019).

The native Amazonian species commonly used for oil extraction are Brazil nut, Tucumã, Açaí, Andiroba, Ucuubá, and Murumuru, among others. However, other potential sources of oil have been researched, including Patauá (Oenocarpus bataua). According to Rodrigues et al. (2010), the average oil content in the pulp of Pataua is $41.78 \%$ and around $1 \%$ in the seeds. Patauá pulp and seeds are rich in unsaturated fatty acids, mainly oleic acid ( $\omega-9)$ (Rodrigues et al., 2010; Dlugogorski et al., 2012; Santos et al., 2013b; Carrillo et al., 2018; Flores et al., 2018; Pereira et al., 2019).

Oils rich in monounsaturated acids have some disadvantages, for example low storage stability due to factors involved in lipid oxidation such as temperature, concentration of oxygen, light, and oxidized metals among others. These factors can change the following oil's properties: physical and chemical composition; colorimetric and sensory characteristics; fatty acid composition; number of elements with oxidation state of -1 , such as peroxides and hydroperoxides, forming volatile compounds such as ketones, aldehydes, alcohols, and others influencing the sensory perceived attributes with the development of rancidity process. They can also change the oil nutritional value due to increased 
acidity and loss of fat-soluble vitamins (Cuvelier \& Maillard, 2012; Santos et al., 2014; Carrillo et al., 2018).

The presence of double bonds in these oils facilitates the attack of oxygen favoring their breaking and subsequent saturation, responsible for rancidity and deterioration of the oils. However, there are ways to predict and monitor these lipid changes and estimate oil shelf life. Methods to determine thermal and oxidative stability and the analysis of spectroscopic profile, among others, can determine important stability characteristics and degree of oxidation. These analyses are conducted to monitor the changes and determine stability during storage measuring their ability to maintain their characteristics during thermal processing (Cuvelier \& Maillard, 2012; Nakavoua et al., 2013; Madeleine-Perdrillat et al., 2014; Oliveira et al., 2017).

The most commonly analyses used in these materials to predict their thermal behavior under progressive temperature rise and dynamic and static controlled atmosphere are: thermogravimetric (TG/DTG) and differential (DTA) analyses and the accelerated test of oxidative stability (OSI), using heat and gas flow to simulate real environment to obtain the results more quickly and efficiently (Nakavoua et al., 2013; Vieira \& Pasquini, 2013; Madeleine-Perdrillat et al., 2014; Santos et al., 2014; Pereira et al., 2019).

Another method used to monitor the behavior of oils based on infrared bands and vibrational frequencies is the Fourier Transform Infrared Spectroscopy (FTIR), which identifies functional groups, double bonds, and chemical bonds of samples. The analysis of IR spectra can determine the composition of the oil sample and identify oxidation reactions, decomposition, and rancidity processes, which are evidenced by the presence of compounds or functional groups characteristic of secondary oxidation and rancidity (Nakavoua et al., 2013; Vieira \& Pasquini, 2013; Gardette \& Baba, 2013; Araújo et al., 2018).

Therefore, the objective of this research is to evaluate the quality parameters, the chromatographic, thermogravimetric and spectroscopic profile of Patauá oil (oenocarpus bataua), in order to deepen the knowledge of its properties and address other potential applications in various industry sectors.

\section{Materials and methods}

The Patauá fruits used in this study were donated by the Amazon Oil company (2015 fruit season), located in the city of Ananindeua, northern Pará State.

The oil was obtained by hydraulic pressing at the laboratory of food analysis of the School of Nutrition, Federal University of Para, and was stored at $-7^{\circ} \mathrm{C}$ until analysis.

\subsection{Physicochemical characterization of the oil}

The oil obtained using a MARCON MPH-15 hydraulic press (Marcon Metallurgical industry Ltda, Brazil) a capacity of 15 tons of pressure and subjected to analyses to assess its quality. All analyses were performed according to the Recommended Practices of the American Oil Chemists' Society (AOCS) (American Oil Chemists Society, 1998).
Acidity value: determined according to the AOCS Cd 3d-63 method (American Oil Chemists Society, 1998).

Peroxide value: determined according to the AOCS Cd 8-53 method (American Oil Chemists Society, 1998).

\subsection{Colorimetric analysis}

The international standards and the nomenclature for the measurement of color used by the food industry were defined by the CIE (Commission Internationale de l'éclairage, 1931). In this study, the CIELAB system $\left(\mathrm{L}^{*}, \mathrm{a}^{*}, \mathrm{~b}^{*}\right)$ described by Motta (2005) was used.

The equipment chroma meter Minolta CR-310 (Minolta Co., Ltd., Japan) was set up using the following parameters defined by the manufacturer: $L^{\star}=97.51, a^{\star}=+0.34$, and $b^{\star}=+1.73$. The result expresses color change $(\Delta \mathrm{E})$ according to Equation 1.

$\Delta \mathrm{E}^{*}=\left[\left(\Delta \mathrm{L}^{*}\right)^{2}+\left(\Delta \mathrm{a}^{*}\right)^{2}+\left(\Delta \mathrm{b}^{*}\right)^{2}\right]^{1 / 2}$

\subsection{Fatty acid profile characterization}

The preparation of methyl esters of fatty acids followed the methodological recommendations of the international organization for standardization, ISO 5509 (International Organization for Standardization, 1978). Samples of $1.0 \mathrm{~g}$ of oil were weighed, added with $10.0 \mathrm{~mL}$ of $\mathrm{n}$-heptane, and stirred.

Next, $0.50 \mathrm{~mL}$ of $2.0 \mathrm{~mol}^{-1} \mathrm{NaOH}$ in methanol was added and stirred again for 20 seconds. After phase separation, the supernatant was collected for further analysis by gas chromatography.

The analyses were performed on a Varian 430-GC (Varian Inc., USA) gas chromatograph coupled to a microcomputer equipped with Galaxie Chomatography software. The chromatographic conditions were as follows: fused silica capillary column SP-2560 (SUPELCO USA), $100 \mathrm{~m}$ length, $0.25 \mathrm{~mm}$ inner diameter, and coated with $0.2 \mu \mathrm{m}$ Polyethylene glycol.

The operating conditions were as follows: Split Injection, 50:1 ratio; column temperature programming rate - Initial temperature $100{ }^{\circ} \mathrm{C}$, increase $4 \%$ min to final temperature of $240{ }^{\circ} \mathrm{C}$; carrier gas - helium at $37 \mathrm{psi}$ and linear velocity of $20 \mathrm{~cm} /$ second; make-up gas - helium at $29 \mathrm{~mL} / \mathrm{minute}$; injector temperature $250{ }^{\circ} \mathrm{C}$ - Varian CP8410 (Autosampler); and detector temperature $250^{\circ} \mathrm{C}$. The qualitative composition was determined by comparison of the retention peak times with the respective fatty acids standards.

The quantitative composition was determined by normalization of the area and expressed as mass percentage (Díaz Gamboa \& Gioielli, 2003), according to AOCS Ce 1-62 official method (American Oil Chemists Society, 1997). All samples were analyzed in triplicate, and the results are the mean of triplicates.

\subsection{Thermogravimetric and differential analyses}

Thermogravimetric and differential analyses were performed on a Shimadzu-DTG-60 H (Shimadzu Corporation, Japan) thermo balance with the following parameters: air and nitrogen 
flow: $60 \mathrm{~mL} /$ minute, heating ramp: $10^{\circ} \mathrm{C} /$ minute, temperature range from 20 to $600^{\circ} \mathrm{C}$, alumina crucible and $5 \mathrm{mg} \pm 0.5$ mass.

\subsection{Thermal stability analysis}

Analyses of oxidative stability were performed using the Rancimat method (Metrohm 743- Metrohm AG, Switzerland) under the following parameters: temperature of $100^{\circ} \mathrm{C}$, air flow of $10 \mathrm{~mL} / \mathrm{h}$, and an oil sample of $5 \mathrm{~g}$ (American Oil Chemists Society, 1996; Cd 12b-92).

\subsection{Infrared absorption spectroscopy}

The spectroscopic profile of the oil samples was determined by FTIR (Fourier Transform Infrared Spectroscopy) using an IR 100 (Thermo Electron Corporation - Waltham, USA) spectrophotometer with $2 \mathrm{~cm}^{-1}$ resolution and optical range of $4000-400 \mathrm{~cm}^{-1}$ with 64 scans.

\section{Results and discussion}

\subsection{Physicochemical characterization of the oil}

The physicochemical characteristics of the oil obtained in the analyses are shown in Table 1.

The results presented in Table 1 represent parameters related to the conservation and quality of the oil. The mean acidity value found was $1.40 \mathrm{mgKOH} / \mathrm{g}$. According to the National Health Surveillance Agency (ANVISA), this index is one of the most important quality control parameters of oils. Anvisa has established the standards for unrefined cold-pressed oils as maximum values of $4.0 \mathrm{mg} \mathrm{KOH} / \mathrm{g}$ oil (Brasil, 2005).

Another quality parameter evaluated was the peroxide value, which identifies the early stages of oil and fat oxidation and determine their quality, considering the fact that the higher the peroxide value, the greater the susceptibility to oxidative rancidity (Brasil, 2005).

The mean peroxide value obtained in this study was $9.640 \mathrm{mEqkg}^{-1}$. This value is lower than those reported by other studies on different oils; the Brazilian legislation establishes peroxides values below $20 \mathrm{mEqkg}{ }^{-1}$ for virgin olive oil.

Despite the discrepancy in the peroxide value found, the oil has good quality, according to the standards for peroxide value established by ANVISA, maximum values in the range of $15 \mathrm{mEqkg}^{-1}$ (Brasil, 2005).

\subsection{Colorimetric analysis of the oil}

In addition to other quality assessment analyses, assessing the color parameters in plant products can provide indications of quality changes. Oil color is commonly assessed in terms of sensory aspects and chemical or physical analysis.

The results of the Pataua oil color analysis indicated color variation $(\Delta \mathrm{E})$, as shown in Table 2.

The parameter $\mathrm{a}^{*}$ indicated tendency to green color $\left(-\mathrm{a}^{*}\right)$, and the $b^{\star}$ value indicated tendency to yellow $\left(+b^{\star}\right)$. The overall results show variation in color $(\Delta \mathrm{E})$, as shown in Table 2 .
The results found for Patuá oil are similar to those of other Amazonian oils, such as Brazil nut oil, showing the same color tendencies although obtained from different forms of extraction. According to the parameter $\mathrm{a}^{*}$, these oils tended to green, and according to $\mathrm{b}^{\star}$, they tended to yellow $\left(+\mathrm{b}^{\star}\right)$ (Santos et al., 2012, 2013a).

In terms of sensory properties, these results confirm the instrumental data. According to Rubio-Rodríguez et al. (2008), the quality of an oil during storage can also be assessed by this method, in which it would be seen that the color parameter $\mathrm{a}^{*}$ decreases during storage, increasing its tendency to green $\left(-\mathrm{a}^{\star}\right)$ and the parameter $\mathrm{b}^{*}$ decreases at temperatures around $20^{\circ} \mathrm{C}$, indicating greater tendency to yellow $\left(+b^{*}\right)$. The changes in these parameters may be related to lipid oxidation reactions, common in oils during storage.

\subsection{Fatty acid profile characterization}

The results of the analyses of the fatty acid profile of Patauá oil are shown in Table 3.

The results in Table 3 show great predominance of the following fatty acids: oleic acid with mean value of $71.79 \%$ and palmitic acid, $13.63 \%$. The predominance of unsaturated fatty acids, especially the linoleic acid (C18:2, $\omega-6)$ and linolenic acid $(\mathrm{C} 18: 3, \omega-3)$, shows the nutritional and functional potential of this oil.

Table 1. Physicochemical characteristics of Patuá oil.

\begin{tabular}{cc}
\hline Properties & Values Obtained \\
\hline Acidity value $(\mathrm{mgKOH} / \mathrm{g})$ & $1.40 \pm 0.09$ \\
Peroxide value $\left(\mathrm{mEqkg}^{-1}\right)$ & $9.64 \pm 3.58$ \\
\hline
\end{tabular}

Table 2. Instrumental color analysis.

\begin{tabular}{cc}
\hline Analysis & Oil \\
\hline $\mathrm{L}^{*}$ & $36.00 \pm 0.03$ \\
$\mathrm{a}^{*}$ & $-2.02 \pm 0.41$ \\
$\mathrm{~b}^{*}$ & $15.05 \pm 0.37$ \\
$\Delta \mathrm{E}$ & $62.98 \pm 0.00$ \\
\hline
\end{tabular}

Data represent the mean \pm standard deviation of triplicate assays $(n=3)$.

Table 3. Fatty acid profile of Patauá oil.

\begin{tabular}{ccc}
\hline Carbon chain & Fatty acid profile & Patauá oil (\%) \\
\hline$(\mathrm{C} 12: 0)$ & Lauric Acid & $2.23 \pm 0.03$ \\
$(\mathrm{C} 16: 0)$ & Palmitic Acid & $13.63 \pm 0.01$ \\
$(\mathrm{C} 16: 1)$ & Palmitolic Acid & $0.86 \pm 0.02$ \\
$(\mathrm{C} 18: 0)$ & Stearic Acid & $2.95 \pm 0.12$ \\
$(\mathrm{C} 18: 1, \omega-9)$ & Oleic Acid & $71.79 \pm 0.02$ \\
$(\mathrm{C} 18: 2, \omega-6)$ & Linoleic Acid & $4.72 \pm 0.03$ \\
$(\mathrm{C} 18: 3, \omega-3)$ & Linolenic Acid & $0.51 \pm 0.00$ \\
$(\mathrm{C} 20: 1)$ & Erucic Acid & $0.46 \pm 0.00$ \\
Total unsaturated fatty acids & & 78.34 \\
Total saturated fatty acids & & 19.27 \\
TOTAL & & 97.61 \\
\hline
\end{tabular}

Data represent the mean \pm standard deviation of duplicate assays. 
These acids correspond, respectively, to the omega fatty acid series $\omega-6$ and $\omega-3$, considered as essential fatty acids; i.e., fatty acids that humans must ingest because the body requires them for good health but cannot synthesize.

The unsaturated fatty acids stand out (mainly the oleic and linoleic acids), including the monounsaturated (MUFA) and polyunsaturated (PUFA) acids, which account for an average of $78.34 \%$ of the total fatty acids. The others are saturated fatty acids (SFA), with an average of $19.27 \%$, with predominance of palmitic and stearic acids.

The fatty acid composition varies widely in the seeds or kernels of different plant species. Table 4 shows the percent composition of fatty acids in different oilseeds.

The fatty acid profile of these oilseeds show that they are good sources of unsaturated fatty acids, especially monounsaturated and polyunsaturated acids, which if combined demonstrate the predominance of the functional aspects of the oils of these oilseeds.
This table shows the similarity between these oilseeds in terms of fatty acid composition, with values around 20 to $25 \%$ of saturated fatty acids and approximately 55 to $80 \%$ of unsaturated fatty acids, with a high prevalence of polyunsaturated fatty acids. These results confirm the nutritional and functional importance of these oilseeds, which may be related to their high content of $\omega-6$ and $\omega-9$ fatty acids and significant content of $\omega-3$ fatty acids.

Foods containing $\omega-6$ and $\omega-3$ fatty acids are considered as a special class of molecules since they have the capacity to convert into eicosanoids and docosanoids, lipid mediators that include prostaglandins, leukotrienes, thromboxanes, and lipoxins, related to inflammatory processes (Santos et al., 2013a).

\subsection{Thermogravimetric and differential analyses}

The graphic behavior exhibited in the thermogravimetric and differential analyses of Patauá oil are shown in Figure 1.

Table 4. Comparison of fatty acid profile of oilseeds.

\begin{tabular}{|c|c|c|c|c|c|c|c|c|}
\hline Samples & C16:0 & C16:1 & C18:0 & C18:1 & C18:2 & C18:3 & C20:0 & C20:1 \\
\hline Patauá & 13.63 & 0.86 & 2.95 & 71.79 & 4.72 & 0.51 & $\mathrm{ND}$ & 0.46 \\
\hline Almond & 6.85 & 0.63 & 1.29 & 69.24 & 21.52 & 0.16 & 0.16 & ND \\
\hline Brazil nut & 13.5 & 0.33 & 11.77 & 29.09 & 42.80 & 0.20 & 0.54 & 0.21 \\
\hline Cashew nut & 9.93 & 0.36 & 8.70 & 57.24 & 20.80 & 0.23 & 0.97 & 0.25 \\
\hline Macadamia & 8.37 & 17.28 & 3.17 & 65.15 & 2.31 & 0.06 & 2.28 & ND \\
\hline Peanut & 11.00 & 0.15 & 2.66 & 38.41 & 44.60 & 0.58 & 1.57 & $\mathrm{ND}$ \\
\hline Pecan & 4.28 & 0.09 & 1.80 & 40.63 & 50.31 & 0.65 & $\operatorname{Tr}$ & 1.21 \\
\hline Walnut & 6.70 & 0.23 & 2.27 & 21.0 & 57.46 & 11.58 & 0.08 & ND \\
\hline
\end{tabular}

ND = Not determined; $\mathrm{Tr}=$ Trace. Source: Adapted from Santos (2012).

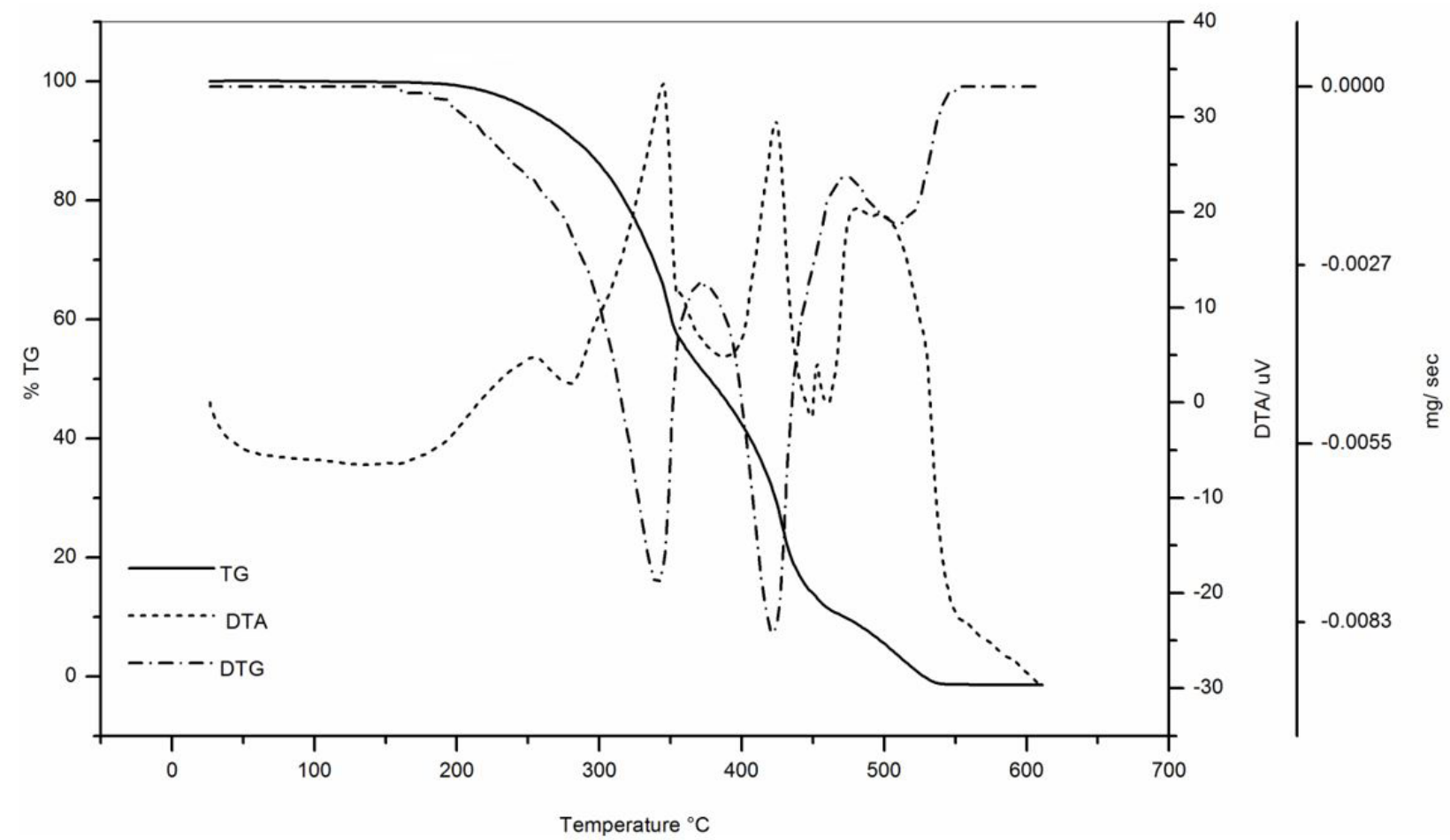

Figure 1. Thermogravimetric and Differential behavior of Patauá oil. 
The thermogravimetric and differential curves (TG/DTG and DTA) of Patauá oil show a small mass loss close to $100{ }^{\circ} \mathrm{C}$, related to the boiling point of water present in this material.

There was constant mass loss rate upon temperature increase, but it decreased sharply after the temperature of $200{ }^{\circ} \mathrm{C}$ and continued decreasing until almost total decomposition of the sample after $400{ }^{\circ} \mathrm{C}$.

The first derivative curve (DTG) of the oil shows the behavioral changes in greater detail. Successive peaks correspond to changes in the material with gradual temperature increase and possible noise picked up by the equipment.

The main peak shown is situated between 380 and $420{ }^{\circ} \mathrm{C}$. The thermal behavior exhibited by the oil indicates possible oxidation, decomposition, and other processes that degrade the fatty material, demonstrating its ability to resist to mass loss and temperature under dynamic controlled atmosphere.

The DTA curve shows endothermic behavior with peaks between 300 and $380^{\circ} \mathrm{C}$, resulting from possible uptake of oxygen from the atmosphere of analysis, and two sharper exothermic peaks between 400 to $500{ }^{\circ} \mathrm{C}$, which are explained by the final oxidation processes of the oil and the final material degradation with subsequent release of energy in the form of heat.

\subsection{Thermal stability analysis}

The oxidative stability of the Patauá oil showed oxidation induction time around 2.79 hours, i.e., time at which the raw material is able to withstand oxidation and temperature of $100^{\circ} \mathrm{C}$, parameters used to determine thermal and oxidative stability.
This result is directly related to the presence of antioxidants and percentage of unsaturated fatty acids in the oil, which, in general, are inversely proportional parameters.

\subsection{Infrared absorption spectroscopy}

As can be seen in Figure 2, the infrared spectrum of the oil show broad bands ranging from below $3000 \mathrm{~cm}^{-1}$ to $2750 \mathrm{~cm}^{-1}$, characteristic of methyl (-CH3); methylenic (-CH2), and methyl groups $(-\mathrm{CH})$. These spectral bands are similar to those of buriti and sesame oils but are lower than those of the linseed oil (above $3000 \mathrm{~cm}^{-1}$ ), indicating possible oxidation of this oil (Silverstein et al., 2000; Albuquerque et al., 2003; Blayo et al., 2001).

The peak around $1750 \mathrm{~cm}^{-1}$ is characteristic of the carbonyl group $(\mathrm{C}=\mathrm{O})$ : methyl esters, ketones, and aldehydes, which are commonly present in long-chain fatty acids, confirming the result of the fatty acid profile of the Patuá oil. Bands in the range of $1200 \mathrm{~cm}^{-1}$ are related to unsaturated esters functional group (C-O-C). Bands in the region 1290-1040 $\mathrm{cm}^{-1}$ are characteristic of alcohols, esters, ethers, carboxylic acids, and fatty acids (Albuquerque et al., 2003; Blayo et al., 2001; Silverstein et al., 2000).

Bands in the region 2924-2855 $\mathrm{cm}^{-1}$ are related to $\mathrm{C}-\mathrm{H}$ bonds within the hydrocarbon skeleton, characteristic of alkane groups of high intensity and functional groups with double bonds. These unsaturations, are predominantly found in the fatty acid profile of oilseeds, such as those found in the profile of the Pataua oil, confirming the results obtained in the gas chromatography analysis (Silverstein et al., 2000).

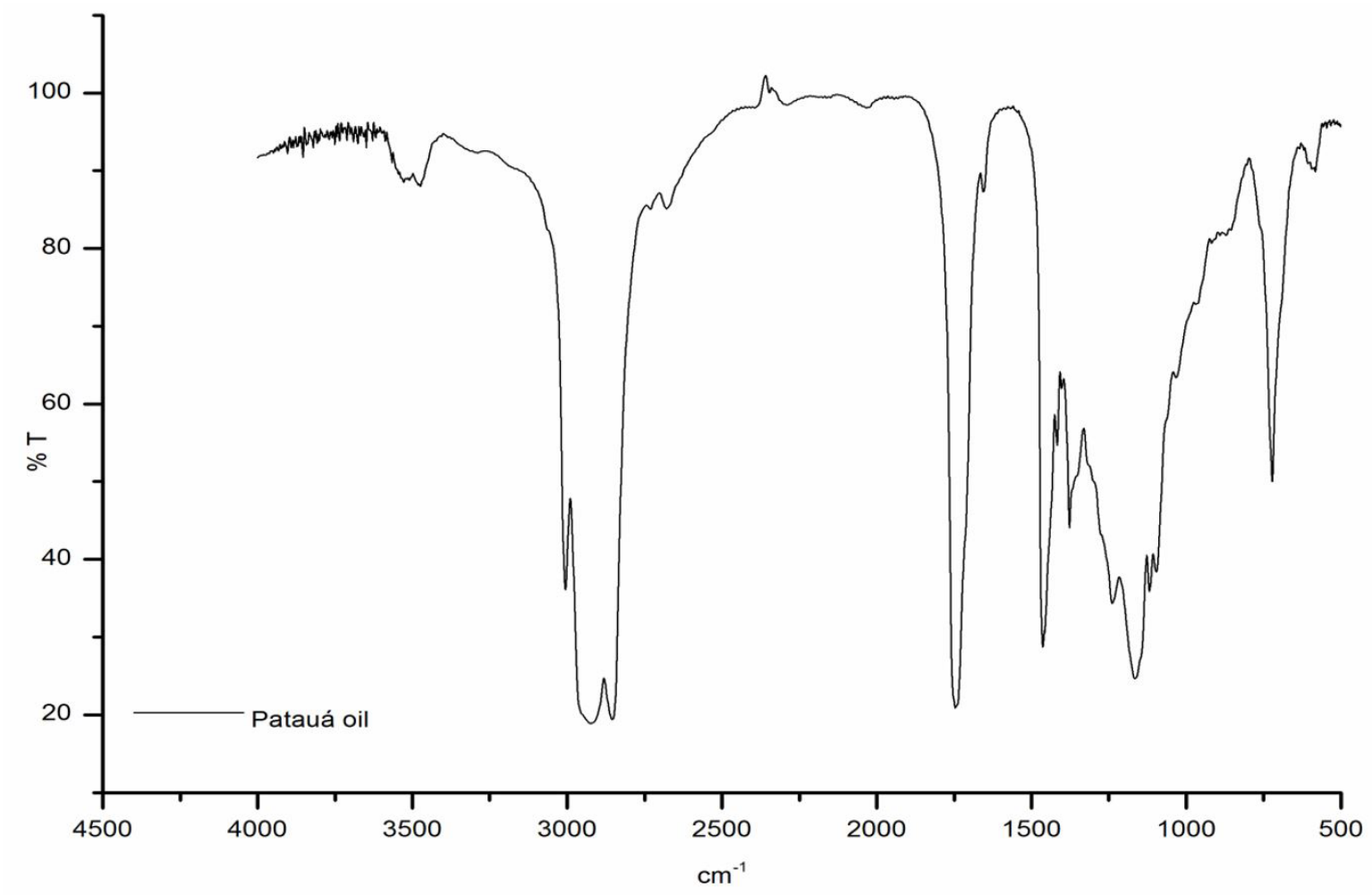

Figure 2. Infrared absorption Spectrum of Patauá oil. 


\section{Conclusions}

The nutritional and functional quality of this material was expressed by the predominance of unsaturated fatty acids, especially oleic, linoleic, and linolenic acids.

The DTA curves showed endothermic and exothermic events in the oil under air atmosphere, with high intensity peaks in region between $300-400{ }^{\circ} \mathrm{C}$ and $300-500{ }^{\circ} \mathrm{C}$.

The results of the accelerated test by the Rancimat method showed thermal oxidative stability of 2.79 hours, with good thermal and oxidative resistance to the parameters of atmosphere and temperature used in this analysis.

The evaluation of the quality parameters and conservation of Patauá oil showed a high quality material, according to the standards established by the Brazilian legislation.

\section{References}

Albuquerque, M. L. S., Guedes, I., Alcantara, P. Jr., \& Moreira, S. G. C. (2003). Infrared absorption spectra of buriti (Mauritia flexuosa L.). Vibrational Spectroscopy, 33(1-2), 127-131. http://dx.doi.org/10.1016/ S0924-2031(03)00098-5.

American Oil Chemists Society - AOCS. (1996). Official methods and recommended practices of the American Oil Chemists' Society. New York: AOCS.

American Oil Chemists Society - AOCS. (1997). Official methods and recommended practices of the American Oil Chemists' Society (4th ed.). Champaign: AOCS.

American Oil Chemists Society - AOCS. (1998). Official methods and recommended practices of the American Oil Chemists' Society (5th ed.). Champaign: AOCS.

Araújo, P. H. F., Barata, P. H. S., Araújo, I. F., Curti, J. M., Amaral, R. R., Bereau, D., Carvalho, J. C. T., \& Ferreira, I. M. (2018). Direct and solvent-free aminolysis of triglyceride from Oenocarpus bataua (Patawa) oil catalyzed by $\mathrm{Al}_{2} \mathrm{O}_{3}$. Catalysis Letters, 148(3), 843-851. http://dx.doi.org/10.1007/s10562-018-2306-7.

Blayo, A., Gandini, A., \& Le Nest, J.-F. (2001). Chemical and rheological characterizations of some vegetable oils derivatives commonly used in printing inks. Industrial Crops and Products, 14(2), 155-167. http://dx.doi.org/10.1016/S0926-6690(01)00079-6.

Brasil, Ministério da Saúde, Agência Nacional de Vigilância Sanitária. (2005, September 22). Aprova o regulamento técnico para óleos vegetais, gorduras vegetais e creme vegetal (Resolução RDC $n^{\circ}$ 270, de 22 de setembro de 2005). Diário Oficial [da] República Federativa do Brasil.

Carrillo, W., Carpio, C., Morales, D., Álvarez, M., \& Silva, M. (2018). Fatty acids content in ungurahua oil (oenocarpus bataua) from ecuador. findings on adulteration of ungurahua oil in ecuador. Asian Journal of Pharmaceutical and Clinical Research, 11(2), 391-394. http://dx.doi.org/10.22159/ajpcr.2018.v11i2.16967.

Chollet, G., Gadenne, B., Alfos, C., \& Cramail, H. (2012). Les lipides: une matière première alternative pour la synthèse de polymères de spécialités. Oilseeds \& Crops and Lipids, 19(1), 39-50. http://dx.doi. org/10.1051/ocl.2012.0428.

Cuvelier, M. E., \& Maillard, M. N. (2012). Stabilité des huiles alimentaires au cours de leur stockage. Oilseeds \& Crops and Lipids, 19(2), 125132. http://dx.doi.org/10.1051/ocl.2012.0440.

Díaz Gamboa, O. W., \& Gioielli, L. A. (2003). Consistência de lípidos estructurados a partir de aceite de pescado y grasa de palmiste.
Grasas y Aceites, 54(2), 122-129. http://dx.doi.org/10.3989/gya.2003. v54.i2.259.

Dlugogorski, B. Z., Kennedy, E. M., \& Mackie, J. C. (2012). Identification and quantification of volatile from oxidation of linseed oil. Industrial \& Engineering Chemistry Research, 51(16), 5645-5652. http://dx.doi. org/10.1021/ie202535d.

Flores, J. A., Konrad, O., Flores, C. R., \& Schroder, N. T. (2018). Inventory data on Brazilian Amazon's non-wood native biomass sources for bioenergy production. Data in Brief, 20, 1935-1941. http://dx.doi. org/10.1016/j.dib.2018.09.050. PMid:30294647.

Gardette, J. L., \& Baba, M. (2013). FTIR and DSC studies of the thermal and photochemical stability of Balanites aegyptiaca oil (Toogga oil). Chemistry and Physics of Lipids, 170-171, 1-7. http://dx.doi. org/10.1016/j.chemphyslip.2013.02.008. PMid:23470324.

International Organization for Standardization - ISO. (1978). Method ISO 5509: animal and vegetable fats and oils: preparation of methyl esters of fatty acids (pp. 1-6). Geneve: ISO.

Irshad, A., Delor-Jestin, F., Chalard, P., \& Verney, V. (2015). Physicochemical durability criteria of oils and linked bio-based polymers. Oilseeds \& Crops and Lipids, 22(1), D107. http://dx.doi.org/10.1051/ ocl $/ 2014048$.

Madeleine-Perdrillat, C., Delor-Jestin, F., Bussière, P.-O., Claire, P. S., Pilichowski, J.-F., \& Baba, M. (2014). Simultaneous UV or thermal exposure and IR detection of evolved vapours: new tool for studying polymer photo-degradation. Journal of Photochemistry and Photobiology A Chemistry, 278, 53-59. http://dx.doi.org/10.1016/j. jphotochem.2013.12.023.

Motta, J. D. (2005). Construção e avaliação do colorímetro para produtos agrícolas (Dissertação de mestrado). Universidade Federal de Campina Grande, Campina Grande.

Nakavoua, A. H. W., Mampouya, D., Loumouamou, A. N., Silou, T., Chalard, P., Verney, V., Guyot, G., Chalchat, J. C., \& Figueredo, G. (2013). Accelerated ageing effects on curcubitea pepo seed oil. Advance Journal of Food Science and Technology, 5(6), 806-821. http://dx.doi.org/10.19026/ajfst.5.3144.

Oliveira, P. D., Rodrigues, A. M. C., Bezerra, C. V., \& Silva, L. H. M. (2017). Chemical interesterification of blends with palm stearin and patawa oil. Food Chemistry, 215, 369-376. http://dx.doi.org/10.1016/j. foodchem.2016.07.165. PMid:27542488.

Pereira, E., Ferreira, M. C., Sampaio, K. A., Grimaldi, R., Meirelles, A. J. A., \& Maximo, G. J. (2019). Physical properties of Amazonian fats and oils and their blends. Food Chemistry, 278, 208-215. http:// dx.doi.org/10.1016/j.foodchem.2018.11.016. PMid:30583364.

Pighinelli, A. L. M. T., Park, K. J., Rauen, A. M., \& Oliveira, R. A. (2009). Optimization of pressing sunflower seeds and its characterization. Revista Brasileira de Engenharia Agrícola e Ambiental, 13(1), 63-67. http://dx.doi.org/10.1590/S1415-43662009000100009.

Rodrigues, A. M. C., Darnet, S., \& Silva, L. H. M. (2010). Fatty acid profiles and tocopherol contents of buriti (Mauritia flexuosa), patawa (Oenocarpus bataua), tucuma (Astrocaryum vulgare), mari (Poraqueiba paraensis) and inaja (Maximiliana maripa) fruits. Journal of the Brazilian Chemical Society, 21(10), 2000-2004. http://dx.doi. org/10.1590/S0103-50532010001000028.

Rubio-Rodríguez, N., Diego, S. M., Beltrán, S., Jaime, I., Sanz, M. T., \& Rovira, J. (2008). Supercritical fluid extraction of the omega-3 rich oil contained in hake (Merluccius capensis-Merluccius paradoxus) by-products: Study of the influence of process parameters on the extraction yield and oil quality. The Journal of Supercritical Fluids, 47(2), 215-226. http://dx.doi.org/10.1016/j.supflu.2008.07.007. 
Santos, A. G. D., Souza, L. D., Caldeira, V. P. S., Farias, M., Fernandes, V. J. Jr., \& Araujo, A. S. (2014). Kinetic study and thermooxidative degradation of palm oil and biodiesel. Thermochimica Acta, 592, 18-22. http://dx.doi.org/10.1016/j.tca.2014.08.006.

Santos, O. V. (2012). Estudo das potencialidades da castanha-do-brasil: produtos e subprodutos (Tese de doutorado). Universidade de São Paulo, São Paulo.

Santos, O. V., Corrêa, N. C. F., Carvalho, R. N. Jr., Costa, C. E. F., França, L. F., \& Lannes, S. C. S. (2013a). Comparative parameters of the nutritional contribution and functional claims of Brazil nut kerners, oil and defatted cake. Food Research International, 51(2), 841-847. http://dx.doi.org/10.1016/j.foodres.2013.01.054.

Santos, O. V., Corrêa, N. C. F., Soares, F. A. S. M., Gioielli, L. A., Costa, C. E. F., \& Lannes, S. C. S. (2012). Chemical evaluation and thermal behavior of Brazil nut obtained by different. Food Research International, 47(2), 253-258. http://dx.doi.org/10.1016/j. foodres.2011.06.038.

Santos, R. F., Fornasari, C. H., Bassegio, D., Souza, S. N. M., \& Secco, D. (2013b). Optimization of oil extraction from high energetic potential plants performed through drying and solvent extraction methods. African Journal of Biotechnology, 12(48), 6761-6765. http://dx.doi. org/10.5897/AJB2013.12409.

Silverstein, R. M., Webster, F. X., \& Kiemle, D. (2000). Identificação espectrométrica de compostos orgânicos (7. ed.). Rio de Janeiro: LTC.

Vieira, F. S., \& Pasquini, C. (2013). Near Infraed emission photometer for measuring the oxidative stability of edible oils. Analytica Chimica Acta, 796, 101-107. http://dx.doi.org/10.1016/j.aca.2013.08.028. PMid:24016589. 